\title{
Seasonal variation of streptococcal vulvo-vaginitis in an urban community
}

\author{
C. A. MORRIS \\ From the Public Health Laboratory, Myrtle Road, Bristol
}

SYNOPSIS A study was made of patients investigated by general practitioners.

Over a three-year period Streptococcus pyogenes (group A) was isolated most commonly from vaginal and vulval swabs collected in the winter. The serotypes of strains indicate that some had probably been derived from the skin and others from the respiratory tract. The two sources are thought to have masked a consistent, but not obvious, seasonal variation in streptococcal vulvovaginitis acquired usually from streptococcal infections of the respiratory tract in winter and from those of the skin in summer.

The seasonal incidence of streptococcal infections of the genital tract of non-puerperal patients outside hospital has received little attention and is the subject of this paper.

As a result of the work of Smith (1931) and Colebrook (1935) it is generally accepted that the principal source of streptococcal infections in childbirth is the respiratory tract of the patient or her attendants. In England and Wales there is a winter predominance of streptococcal infections of the respiratory tract (Cheeseman, 1950; Holmes and Williams, 1958; World Health Statistics Report, 1969) but this is not a feature previously described for streptococcal infections elsewhere in the body. In New Zealand Markham (1959) found no constant seasonal trend in the isolations of $\beta$-haemolytic streptococci from hospital patients investigated in the course of two and a half years. His material included 417 strains of group A streptococci principally from the skin or respiratory tract; only 29 strains were from inflammatory lesions of the vulva, vagina, or cervix, including 16 which were associated with other bacteria of possible pathogenic significance. Boycott (1966) reported an increased number of admissions in winter to the isolation block of Queen Charlotte's Maternity Hospital. In a study of Streptococcus pyogenes mainly from patients in hospital, Boycott isolated 1,287 strains over three years; he found that isolations from the respiratory tract had a winter

'Present address: Public Health Laboratory, Mytton Oak Road, Copthorne, Shrewsbury, SY3 8XH.

Received for publication 15 April 1971. maximum and summer minimum but from other sites the numbers remained constant throughout the year. Only 18 of 310 strains of extra-respiratory origin were from the genital tract and 12 of these were from puerperal patients.

\section{Material and Methods}

THE POPUlation

Between 1966 and 1968, 3,430 vaginal or vulval swabs were examined from patients under the care of family doctors. About $3 \%$ of samples were from children and the remainder from adults. Nine per cent of specimens were from patients who had already received treatment for a vaginal discharge before samples were collected. Just under $2 \%$ of patients had been treated with antibiotics.

In any one year, the proportion of samples per month remained fairly constant. There was no appreciable difference in the number of samples examined in winter compared with summer.

\section{METHOD}

Most samples were collected on charcoal-impregnated swabs and transported to the laboratory in Stuart's thioglycollate medium. Culture plates were inoculated on the day of sampling or the following morning. Beta-haemolytic streptococci were isolated by overnight anaerobic plate culture at $37^{\circ} \mathrm{C}$ on oxalated horse-blood agar with and without crystal violet. The Lancefield's serological group was determined using the formamide method to extract the group specific polysaccharide (Fuller, 1938). Slide agglutination tests for $\mathrm{T}$-antigens and precipitation 


\begin{tabular}{|c|c|c|c|c|c|c|c|c|c|c|}
\hline \multirow[t]{2}{*}{ Period } & \multirow[t]{2}{*}{ 'Season' } & \multicolumn{4}{|c|}{ Str. pyogenes } & \multirow{2}{*}{$\begin{array}{l}\text { 'Delayed } \\
\text { Season' }\end{array}$} & \multicolumn{4}{|c|}{ Str. pyogenes } \\
\hline & & Isolated & $\begin{array}{l}\text { Not } \\
\text { Isolated }\end{array}$ & Total & $\begin{array}{l}\text { Statistical } \\
\text { Significance }\end{array}$ & & Isolated & $\begin{array}{l}\text { Not } \\
\text { Isolated }\end{array}$ & Total & $\begin{array}{l}\text { Statistical } \\
\text { Significance }\end{array}$ \\
\hline $\begin{array}{l}3 \text { years } \\
(1966-68)\end{array}$ & $\begin{array}{l}\text { Winter } \\
\text { (Oct.-Mar.) } \\
\text { Summer } \\
\text { (Apr.-Sept.) } \\
\text { Total }\end{array}$ & $\begin{array}{l}14 \\
43\end{array}$ & $\begin{array}{l}1,747 \\
1,640 \\
3,387\end{array}$ & $\begin{array}{l}1,776 \\
1,654 \\
3,430\end{array}$ & $\begin{array}{l}\chi^{2}=4.279 \\
P<0.05\end{array}$ & $\begin{array}{l}\text { Late winter } \\
\text { (Nov.-Apr.) } \\
\text { Late summer } \\
\text { (May-Oct.) } \\
\text { Total }\end{array}$ & $\begin{array}{l}31 \\
12 \\
43\end{array}$ & $\begin{array}{l}1,684 \\
1,703 \\
3,387\end{array}$ & $\begin{array}{l}1,715 \\
1,715 \\
3,430\end{array}$ & $\begin{array}{l}\chi^{2}=8.502 \\
P<0.01\end{array}$ \\
\hline $\begin{array}{l}2 \text { years } \\
(1967-68)\end{array}$ & $\begin{array}{l}\text { Winter } \\
\text { Summer } \\
\text { Total }\end{array}$ & $\begin{array}{l}27 \\
11 \\
38\end{array}$ & $\begin{array}{l}1,331 \\
1,170 \\
2,501\end{array}$ & $\begin{array}{l}1,358 \\
1,181 \\
2,539\end{array}$ & $\begin{array}{l}\chi^{2}=4.785 \\
P<0.05\end{array}$ & $\begin{array}{l}\text { Late winter } \\
\text { Late summer } \\
\text { Total }\end{array}$ & $\begin{array}{l}27 \\
11 \\
38\end{array}$ & $\begin{array}{l}1,270 \\
1,231 \\
2,501\end{array}$ & $\begin{array}{l}1,297 \\
1,242 \\
2,539\end{array}$ & $\begin{array}{l}\chi^{2}=6.156 \\
\mathrm{P}<0.02\end{array}$ \\
\hline $\begin{array}{l}1 \text { year } \\
\text { (1968) }\end{array}$ & $\begin{array}{l}\text { Winter } \\
\text { Summer } \\
\text { Total }\end{array}$ & $\begin{array}{r}19 \\
5 \\
24\end{array}$ & $\begin{array}{r}769 \\
642 \\
1,411\end{array}$ & $\begin{array}{r}788 \\
647 \\
1,435\end{array}$ & $\begin{array}{l}\chi^{2}=4.846 \\
P<0.05\end{array}$ & $\begin{array}{l}\text { Late winter } \\
\text { Late summer } \\
\text { Total }\end{array}$ & $\begin{array}{r}19 \\
5 \\
24\end{array}$ & $\begin{array}{r}706 \\
705 \\
1,411\end{array}$ & $\begin{array}{r}725 \\
710 \\
1,435\end{array}$ & $\begin{array}{l}\chi^{2}=6.888 \\
\mathbf{P}<0.01\end{array}$ \\
\hline
\end{tabular}

Table I Seasonal incidence of Str. pyogenes from vaginal swabs of non-hospital patients

tests for $\mathbf{M}$-antigens were performed at the Public Health Laboratory, Radcliffe Infirmary, Oxford.

\section{Results}

Forty-three strains of Strep. pyogenes were isolated from 3,430 samples. In Table I the isolations are related to the season when samples were collected and to the number of patients examined. Statistically there is a significantly higher isolation rate from samples examined in the winter than in the summer; this is most marked if the winter season is regarded as November to April ('delayed season') rather than October to March. The winter predominance is true for the three years and also for the shorter periods of the most recent two and one years. Strep. pyogenes

\begin{tabular}{|c|c|c|c|c|c|}
\hline \multirow[t]{2}{*}{ Strain $(s)$} & \multirow{2}{*}{$\begin{array}{l}\text { Month }(s) \text { of } \\
\text { Isolation }\end{array}$} & \multirow{2}{*}{$\begin{array}{l}\text { Age of } \\
\text { Patient }(s) \\
\text { (years) }\end{array}$} & \multicolumn{2}{|c|}{ Serological Type } & \multirow{2}{*}{$\begin{array}{l}\text { Probable } \\
\text { Origin }\end{array}$} \\
\hline & & & $T$ & $M$ & \\
\hline $\begin{array}{l}1-3 \\
4 \\
5 \text { and } 6 \\
7 \\
8 \text { and } 9 \\
10 \\
11-14\end{array}$ & $\begin{array}{l}\text { Nov., May, Oct. } \\
\text { Mar. } \\
\text { Jan., Mar. } \\
\text { Mar. } \\
\text { Oct., July } \\
\text { Nov. } \\
\text { Jan., Feb., May, } \\
\text { Feb. }\end{array}$ & $\begin{array}{l}6,21,39 \\
58 \\
22,30 \\
41 \\
2 \frac{1}{2}, 7 \\
6 \\
7,29,39 \\
48\end{array}$ & $\begin{array}{l}1 \\
3 \\
3 / \mathrm{B} 3264 \\
3 / \mathrm{B} 3264 \\
4 \\
6\end{array}$ & $\begin{array}{c}\frac{1}{-} \\
\frac{1}{3} \\
-\end{array}$ & $\begin{array}{l}\mathbf{R} \\
\mathbf{D} \text { or } \mathbf{R} \\
\mathbf{D} \text { or } \mathbf{R} \\
\mathbf{R} \\
\mathbf{R} \\
\mathbf{R}\end{array}$ \\
\hline $\begin{array}{l}15 \text { and } 16 \\
17 \text { and } 18 \\
19 \text { and } 20 \\
21-23 \\
24 \\
25 \\
26 \text { and } 27 \\
28-30 \\
31 \\
32 \text { and } 33\end{array}$ & $\begin{array}{l}\text { June, Mar. } \\
\text { Oct., Jan. } \\
\text { Oct., Aug. } \\
\text { Jan., Dec., Sept. } \\
\text { Jan. } \\
\text { Nov. } \\
\text { Dec., Mar. } \\
\text { Oct., Sept., Sept. } \\
\text { Feb. } \\
\text { Mar., Mar. }\end{array}$ & $\begin{array}{l}3,65 \\
5,22 \\
22,65 \\
6,54,63 \\
4 \\
38 \\
35,39 \\
35,35,49 \\
37 \\
20,70\end{array}$ & $\begin{array}{l}12 \\
12 \\
\text { Imp. } 19 \\
22 \\
25 \\
25 / \text { Imp. } 19 \\
28 \\
4 / 28 \\
28\end{array}$ & $\begin{array}{l}\frac{12}{18} \\
\frac{22}{-} \\
\frac{28}{28} \\
-\end{array}$ & $\begin{array}{l}\text { R } \\
\mathbf{R} \\
\mathbf{R} \\
? \mathbf{D} \\
? \mathbf{R} \\
\mathbf{D} \\
\mathbf{D} \\
\mathbf{R} \\
\mathbf{R} \\
\text { ?D }\end{array}$ \\
\hline
\end{tabular}

Table II Serotypes of Streptococcus pyogenes from vaginal and vulval swabs from non-hospital patients

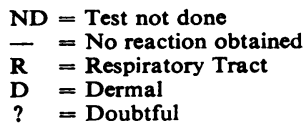

was isolated from nearly one in five samples from children but from only just over $1 \%$ of samples from women of childbearing age.

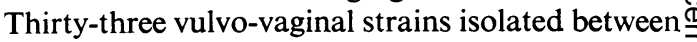
1967 and 1969 were sent for further identification. The serotypes are recorded in Table II where they are related to the month of isolation, age of the $\vec{\varphi}$ patient, and the probable source of streptococcibefore they reached the genital tract. Eighteen strains were shown to have type specific M-protein antigens. Of the strains which were not M-typeable, those of T-types 6 and 12 may be presumed to be derived from the corresponding M-type but other $\mathbb{D}$ strains may have been associated with one of several M-antigens (Parker, 1967).

\section{Discussion}

Streptococcal vulvo-vaginitis is an uncommon condi-응 tion affecting children more often than adults. The source of infection is the respiratory tract or skin of the patient or her contacts. At any one time from none to $20 \%$ of a normal urban population may have Strep. pyogenes in the nasopharynx (Wilson윽 and Miles, 1964) but normal skin carriage is un- $\rightarrow$ common and usually transient (Colebrook and?. Maxted, 1933). Some strains have been found on N normal skin for two weeks before the appearance of a lesion (Dudding, Burnett, Chapman, and Wannamaker, 1970). Group A streptococci are rarely found $\omega$ in the normal genital tract but occasionally may be? isolated from the vulva (Morris and Morris, 1967). .0

Sometimes it is possible, from the history and by examining specimens from the patient and her home ${ }^{?}$ contacts, to trace the source of infection. When this 0 cannot be done, the probable source may be inferred ${ }_{\mathbb{D}}$ from the serotype of streptococcus isolated; this $\bigcirc$

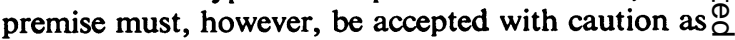
many types can be found in respiratory and non- 
respiratory sites. The winter predominance of streptococcal vulvo-vaginitis suggests that some infections had been acquired from the respiratory tract. Strains of types $1,3,6,4 / 18,12,18$, and 28 are more typically associated with epidemics of tonsillitis or pharyngitis (Boissard and Fry, 1966; Matanoski, Price, and Ferencz, 1968) whereas the 25/Imp 19 and 3/B3264 complexes are more characteristic of streptococcal pyoderma (Parker, Tomlinson, and Williams, 1955; Dillon, Moody, Maxted, and Parker, 1967). It is of interest that included in the strains associated with vulvo-vaginitis are types $1,4,12$, and 25 ; these serotypes are among the few shown as yet to be related to acute nephritis (Wannamaker, 1970).

If Strep.pyogenes in the genital tract was acquired, as suggested here, from a previous respiratory or skin source, then, in a temperate climate, types of presumed respiratory origin would be expected to be isolated most commonly in the winter and those of dermal origin in the summer, when the skin is more exposed and subject to trauma. This hypothesis is only partly supported by the findings recorded in Table II; however, the numbers are small, the monthly distribution irregular, and some strains may have been present in a carrier state for several weeks before the patient visited her doctor. The difference in seasonal distribution between strains of respiratory and dermal origin is relative rather than absolute.

In this study Strep. pyogenes was found in association with Trichomonas vaginalis in one patient and with Staphylococcus aureus in another, but never with gonococci or Candida albicans. Symptoms were usually acute in patients with Strep. pyogenes, a feature less typical of those with trichomoniasis or staphylococcal infections. There is unfortunately scanty information on the response to penicillin of the patients with streptococcal infection. Some practitioners helped by sending additional pre-treatment and post-treatment vaginal and throat swabs but the follow up was to a large extent unsatisfactory. Clinical cure has been presumed when no further sample was received for examination.

Streptococcal vulvo-vaginitis in non-puerperal patients is uncommon and consequently may not be suspected by the general practitioner. The diagnosis can be confirmed speedily by the laboratory and a rapid response expected to antibiotic treatment. Concomitant streptococcal infection elsewhere in the patient and in her home contacts are common and should be looked for and treated.

I wish to thank Dr W. H. H. Jebb for identifying the $\mathbf{M}$ and $\mathrm{T}$ types of streptococci.

\section{References}

Boissard, J. M., and Fry, R. M. (1966). Streptococcal school outbreaks: a method of investigation and control. J. Hyg. (Camb.), 64, 221-230.

Boycott, J. A. (1966). Seasonal variations in streptococcal infections. Lancet, 1, 706-707.

Cheeseman, E. A. (1950). Epidemics in schools. Spec. Rep. Ser. med. Res. Coun. (Lond.), No. 271.

Colebrook, D. C. (1935). The source of infection in puerperal fever due to haemolytic streptococci. Spec. Rep. Ser. med. Res. Coun. (Lond.), No. 205.

Colebrook, L., and Maxted, W. R. (1933). Antisepsis in midwifery. J. Obstet. Gynaec. Brit. Cwlth (Emp.), 40, 966-990.

Dillon, H. C., Jr., Moody, M. D., Maxted, W. R., and Parker, M. T. (1967). The epidemiology of impetigo and acute glomerulonephritis. Amer. J. Epidem., 86, 710-723.

Dudding, B. A., Burnett, J. W., Chapman, S. S., and Wannamaker, L. W. (1970). The role of normal skin in the spread of streptococcal pyoderma. J. Hyg. (Lond.), 68, 19-28.

Fuller, A. T. (1938). The formamide method for the extraction of polysaccharides from haemolytic streptococci. Brit. J. exp. Path., 19, 130-139.

Holmes, M. C., and Williams, R. E. O. (1958). Streptococcal infections among children in a residential home. J. Hyg. (Camb.), 56, 43-72.

Markham, N. P. (1959). Streptococcal infections. N.Z. med. J., 58, 179-183.

Matanoski, G. M., Price, W. H., and Ferencz, C. (1968). Epidemiology of streptococcal infections in rheumatic and non-rheumatic families. Amer. J. Epidem., 87, 179-225.

Morris, C. A., and Morris, D.F. (1967). 'Normal'vaginal microbiology of women of childbearing age in relation to the use of oral contraceptives and vaginal tampons. J. clin. Path., 20, 636-640.

Parker, M. T. (1967). International survey of the distribution of serotypes of Streptococcus pyogenes (Group A streptococci). Bull. World Hlth Org., 37, 513-527.

Parker, M. T., Tomlinson, A. J. H., and Williams, R. E. O. (1955) Impetigo contagiosa. J. Hyg. (Lond.), 53, 458-473.

Smith, J. (1931). Causation and Source of Infection in Puerperal Fever. (Depart of Health for Scotland). HMSO, Edinburgh.

Wannamaker, L. W. (1970). Differences between streptococcal infections of the throat and of the skin. New Engl. J. Med., 282, 23-30, 78-85.

Wilson, G. S., and Miles, A. A. (1964). Topley and Wilson's Principles of Bacteriology and Immunity, 5th ed.,p. 2473. Arnold, London.

World Health Statistics Report (1969). Infectious Diseases, no. 7, p. 384 . 